\title{
Güncellenmiş Uluslararası Rehberler Doğrultusunda Ektopik Gebeliklere Yaklaşım
}

\author{
Sümeyya Betül KIZRAK ${ }^{1}$, (iD) Aytül HADIMLI², (iD)Birsen KARACA SAYDAM ${ }^{3}$
}

'MSc, Ege Üniversitesi Sağlık Bilimleri Enstitüsü Ebelik Anabilim Dalı Doktora Öğrencisi, İzmir, Türkiye.

${ }^{2}$ Dr. Öğr. Üyesi, Ege Üniversitesi Sağlık Bilimleri Fakültesi Ebelik Bölümü, İzmir, Türkiye.

${ }^{3}$ Doç. Dr, Ege Üniversitesi Sağlık Bilimleri Fakültesi Ebelik Bölümü, İzmir, Türkiye.

\begin{abstract}
Öz
Ektopik (ekstrauterin, dış) gebelik blastokistin uterusun endometriyal kavitesi dışında herhangi bir yere yerleşmesidir. Dünyada rapor edilen tüm gebeliklerin \%1-2'sini oluşturur. Ülkemizde son yıllarda cinsel ilişki yaşının düşmesi ile cinsel yolla geçen enfeksiyonların daha sık görülmeye başlaması, sezaryen oranındaki yükseklik, kadınların çalışma hayatına daha aktif katılmalarıyla ileri yaş gebeliklerin artması gibi nedenlerle dış gebelik görülme insidansında artış söz konusudur. Seçilen tedavinin başarısının artmasında eğitim, bakım ve danışmanlığın önemine dikkat çekilmektedir. Bu kapsamda acil obstetrik bakım ve yönetiminde aktif rol alan ebelerin ve hemşirelerin dış gebelik hakkında uygun bakım ve danışmanlık hizmetini sunmaları beklenmektedir. Bu derlemede; dış gebelik konusunda var olan bilgilerimize ek olarak jinekoloji literatüründe başvuru kaynağı olan rehberler eşliğinde güncel yaklaşımı gözden geçirmek amaçlanmıştır. Makalenin derlenmesinde; Amerikan Obstetrik ve Jinekoloji Koleji (ACOG), Royal Obstetrik ve Jinekoloji Koleji (RCOG), İngiltere Ulusal Klinik Uygulamaları Mükemmeliyet Enstitüsü (NICE) ve Amerikan Aile Hekimleri Akademisi (AAFP) önerileri incelenmiştir. Ülkemizde ilk trimester gebeliğe bağlı anne ölümlerinin en sık nedeni olan ektopik gebeliğin yönetiminde koruyucu sağlık hizmetleri kapsamında ebe ve hemşirelerin güncel literatürü takip etmeleri kadın sağlığının korunması ve yükseltilmesi açısından değerlidir.
\end{abstract}

Anahtar Sözcükler: Ektopik Gebelik, Rehber, Hemşirelik, Ebelik.

\begin{abstract}
Updated To International Guıdelines Approach to Ectopic Pregnancies

Ectopic (extrauterine) pregnancy, blastocyst is the location of the uterus anywhere outside the endometrial cavity. It constitutes $1 \%$ to $2 \%$ of all pregnancies reported in the world. In our country, there is an increase in the incidence of ectopic pregnancy due to the decrease in the age of sexual intercourse in recent years, the occurrence of sexually transmitted infections more frequently, high cesarean rate, increased participation of advanced age pregnancies with the more active participation of women in working life. Attention is drawn to the importance of education, care and counseling in increasing the success of the selected treatment. In this context, midwives and nurses who take an active role in emergency obstetric care and management are expected to provide appropriate care and counseling services about ectopic pregnancy. In this review; In addition to our existing information on ectopic pregnancy, it is aimed to review the current approach in the gynecology literature, accompanied by guides who are the reference source. In the compilation of the article; Recommendations of the American College of Obstetrics and Gynecology (ACOG), the Royal College of Obstetrics and Gynecology (RCOG), National Institute of Clinical Practices (NICE) and the American Academy of Family Physicians (AAFP) were examined. In the management of ectopic pregnancy, which is the most common cause of maternal deaths due to first trimester pregnancy in our country, it is valuable for the midwives and nurses to follow the current literature in terms of protecting and promoting women's health.
\end{abstract}

Key Words: Ectopic Pregnancy, Guideline, Nursing, Midwifery.

Geliş Tarihi / Received: 12.12.2020 Kabul Tarihi / Accepted: 16.09.2021

Correspondence Author: Dr. Öğr. Üyesi, Ege Üniversitesi Sağlık Bilimleri Fakültesi Ebelik Bölümü, İzmir, Türkiye. Telefon: +90 05335721446 E-posta: aytul.pelik@ege.edu.tr

Cite This Article: Kızrak SB, Hadımlı A, Saydam BK. Güncellenmiş Uluslararası Rehberler Doğrultusunda Ektopik Gebeliklere Yaklaşım. Dokuz Eylül Üniversitesi Hemşirelik Fakültesi Elektronik Dergisi. 2021; 14 (4): 479- 485 
$\mathbf{E}$ ktopik gebelik, döllenmiş ovumun intrauterin boşluğun dışına implante olmasıdır (1-3). Ektopik implantasyonların en sık görüldüğü yer fallop tüpleri olup vakaların \%90'nını oluşturmaktadır. Bununla birlikte, abdomen (\%1), serviks (\%1), over (\%1-3) ve sezaryen skarı (\%1-3) implantasyonu da görülebilir. Ektopik gebeliğin, intrauterin bir gebelik ile birlikte de ortaya çıkması heterotopik gebelik olarak adlandırılır $(4,5)$. Bu durum anatomik plasental bağlanmaya veya embriyonun büyümesine olanak tanımadığından rüptür ve kanama riski söz konusudur. Erken saptanan çoğu ektopik gebelik vakası minimal invaziv cerrahi veya tıbbi tedavi ile başarılı bir şekilde tedavi edilebilmekle birlikte, stabil olmayan bir hastada, cerrahi müdahale gerektiren obstetrik acil bir durumdur (3). Amerikan Hastalık Kontrol ve Önleme Merkezi'ne (CDC) göre ektopik gebelik, rapor edilen tüm gebeliklerin yaklaşık $\% 2$ 'sini olușturmaktadır (3).

Tanı ve tedavi yöntemlerindeki gelişmelere rağmen ektopik gebelik görülme sıklı̆̆ı, risk faktörlerine bağlı olarak son 20 yılda artmıştır. Ülkemizde son yıllarda cinsel ilişki yaşının düşmesi ile cinsel yolla geçen enfeksiyonların daha sık görülmeye başlaması, sezaryen oranındaki yükseklik, kadınların çalışma hayatında daha aktif olmaları nedeniyle ileri yaş gebeliklerin yanı sıra yardımcı üreme tekniklerine olan talebin artması gibi nedenlerle dış gebelik görülme insidansında da artı̧s söz konusudur (6-9).

Erken teşhis ve tedavi için geliştirilen tüm tanı yöntemlerine rağmen ektopik gebeliğe bağlı meydana gelen kanama, ilk trimester maternal mortalite nedenlerindendir (1). ACOG rehberine göre ektopik gebeliğe bağlı oluşan rüptürün 2011-2013 y1lları arasındaki ölümlerin \%2.7'sini oluşturduğu bildirilmiştir (3). Ektopik gebeliğin tedavisinde seçilen yöntem ne olursa olsun hastaların tedaviye uyumunu sağlamada bakım ve eğitim önemlidir. Güncel rehberler incelendiğinde seçilen tedavinin başarılı olabilmesi için bu aşamada verilecek olan eğitim ve danışmanlığın önemine dikkat çekilmektedir. Seçilen her tedavi yönteminin kendi içerisinde bir bakım ve izlem süreci mevcuttur. Bu nedenle acil obstetrik bakım ve yönetiminde aktif rol alan ebelerin ve hemşirelerin ektopik gebelik ve güncel tedavi yöntemleri hakkında bilgi sahibi olmaları beklenmektedir. Kaliteli bir bakımın ve doğru bilgilendirmenin sağlanabilmesi için ebe ve hemşireler yeni tedavi yöntemlerini, tedavinin yan etkilerini, olası komplikasyonları, izlem protokollerini ve bakım gereksinimlerini bilmelidirler. Böylelikle seçilen tedavinin uygulanabilirliği ve etkinliği artacak; anne ölümlerinin önlenmesi sağlanacaktır.

Dünya genelinde kadın sağlığı ve hastalıkları alanında uzmanlar tarafından oluşturulmuş dernek ve enstitüler, düzenli olarak yayınlanan kanıta dayalı uygulamalar ve meta analiz sonuçları ile hastalıkların yönetimi konusunda rehberler hazırlarlar. Bu derlemede; dış gebelik konusunda var olan bilgilerimize ek olarak jinekoloji literatüründe başvuru kaynağı olan rehberler eşliğinde güncel yaklaşımı gözden geçirmek, hemşirelik ve ebelik bakım yaklaşımını açıklamak amaçlanmıştır. Bu bağlamda Amerikan Obstetrik ve Jinekoloji Koleji (ACOG), Royal Obstetrik ve Jinekoloji Koleji (RCOG), İngiltere Ulusal Klinik Uygulamaları Mükemmeliyet Enstitüsü (NICE) ve Amerikan Aile Hekimleri Akademisi (AAFP) güncel önerileri detaylı olarak incelenmiştir.

\section{Gelişme}

\section{Ektopik Gebelik ve Risk Faktörleri}

Ektopik gebelikte risk faktörleri ortak bir etki mekanizmasını paylaşmaktadır. Fallop tüpünün normal işlevine müdahale eden herhangi bir faktör ektopik gebelik riskini arttırır (1). Bir kez ektopik gebelik geçirmiş olan kadınlarda tekrarlayan ektopik gebelik riski yaklaşı \% 10 'dur. İki veya daha fazla ektopik gebelik öyküsü olan kadınlarda ise, tekrarlama riski $\% 25$ 'ten fazladır. Yardımcı üreme teknolojisi yöntemleriyle gebe kalan kadınlar arasında, tüp faktörlü infertilite ve çoklu embriyo transferi gibi bazı faktörler ektopik gebelik riskinde artı̧ ile ilişkilidir. Diğer risk faktörleri arasında sigara içme öyküsü ve 35 yaşından büyük olma gösterilmektedir $(1,3)$. ACOG’un 2018 rehberine göre, Rahim içi araç (RİA) kullanımı ektopik gebelik insidansını arttırmamaktadır. Herhangi bir kontrasepsiyon kullanmayan kadınlarla kıyaslanacak olursa RİA kullanan kadınlarda ektopik gebelik riski daha düşük bulunmuştur. Bunun nedeni RİA'nın gebeliği önlemede oldukça etkin olmasıdır. Bununla birlikte RİA ile meydana gelen gebeliklerin ektopik olma olasılıkları daha yüksektir (3). Yapılan bir çalışmada RİA ile meydana gelen gebeliklerin \%53'nün ektopik olduğu kaydedilmiştir (10). Oral kontraseptif kullanımı, tubal sterilizasyon, kürtaj öyküsü, gebelik kaybı, sezaryen uygulaması gibi faktörler ektopik gebelik riskinde artış ile ilişkilendirilmektedir (3). RCOG, ektopik gebelik için risk faktörleri arasında ameliyat veya enfeksiyon sonrası tubal hasar, sigara ve in vitro döllenmeyi gösterirken kadınların çoğunluğunda tanımlanabilir bir risk faktörü olmadığını belirtmektedir (2).

\section{Ektopik Gebelikte Hasta Değerlendirmesi}

Ektopik bir gebeliğin doğru tedavi edilebilmesi için zamanında ve uygun değerlendirmenin yapılması önemlidir. Klinik öykü, gebelik tarihçesi, semptomların başlangıcı ve yoğunluğu ile ektopik gebelik için risk faktörlerinin gözden geçirilmesi gerekmektedir. Bu ayrıntılar, en doğru tanı ve tedavinin belirlenmesinin yanı sıra tedavinin devam etmesi gereken hızı belirlemeye yardımcı olur (1). Ayrıntılı klinik öyküye ek olarak fiziki muayene ve transvajinal ultrason (TvUSG), ektopik gebeliğin doğru ve zamanında teşhisi için temel tanı araçlarından olmaya devam etmektedir (RCOG kanıt düzeyi B) $(1,3)$. Ultrason ile görselleştirilmiş ektopik gebelikte serum beta-human koryonik gonadotropin hormonu ( $\beta$-hCG) seviyesi de tedavi planlaması için yararlıdır (2). Tanı aşamasında çok düşük seviyelerde bile $\beta$-hCG düzeyi iki günde bir, iki katına çıkmalıdır. 48 saatlik bir ikiye katlamanın olmaması, anormal bir gebeliğin varlığını gösterir ancak implantasyonun nerede olduğunu göstermez. Bu nedenle tanı için tek başına $\beta$-hCG düzeyi yeterli değildir $(1,3)$. $\beta$-hCG değeri ektopik gebelik riskinde tanıda kullanılacaksa olası yanlışlıkları engellemek için bu değerin normal intrauterin gebelikteki kadar yüksek olması gerekir (örneğin, $3.500 \mathrm{mIU} / \mathrm{mL}$ ). Ancak çoğul gebeliği olan kadınların gebeliğin herhangi bir haftasında tekil gebeliğe kıyasla daha yüksek $\beta$-hCG değerine sahip olabilecekleri de unutulmamalıdir (3).

Uterin küretaj yapıldığında elde edilen materyalde koryonik villus tespit edilmesi intrauterin gebeliği onaylamakta ve başka bir değerlendirme gerekmemektedir (AAFP, Kanıt düzeyi C). Koryonik villus elde edilmez ise; 
küretajdan/aspirasyondan 12-24 saat sonra $\beta$-hCG seviyeleri izlenmesi gerekmektedir. $\beta$-hCG düzeyinde en az \%15 azalma görülmez ise ektopik bir gebelikten şüphelenilmesi gerektiği belirtilmiştir. $(1,3)$.

Genel durumu stabil olan ve risk faktörü bulunmayan kadınlarda ektopik gebelik seri $\beta$-hCG ve ultrasonografi ile 7-10 gün içerisinde belirlenmelidir. Tanı hala belirsiz ise tanısal laparoskopi yapılabilir. Ektopik gebelik öyküsü bulunma gibi yüksek riskli gruplarda daha erken dönemde tanısal laparoskopi düşünülebilir (1).

\section{Ektopik Gebelikte Yönetim}

Kesin tanı konulduktan sonra tedavi seçenekleri arasında konservatif yaklaşım, medikal ve cerrahi yer alır. Genel durumu stabil olmayan veya hayatı tehdit eden kanama varlı̆ıında acil cerrahi tedavi endikedir (AAFP, Kanıt düzeyi C). Diğer durumlar için tedavi seçimi riskler, faydalar ve tüm yaklaşımların gerekliliklerini izleme gibi faktörler göz önünde bulundurularak belirlenmelidir (1).

\section{Konservatif Yaklaşım / Bekleme Yaklaşımı}

Ektopik gebelikte birçok tedavi seçeneği olmakla birlikte klinik olarak stabil, USG'de kitle boyutu $3.5 \mathrm{~cm}$ 'den az, düşük seviyede $\beta$-hCG değerlerine sahip ve takibe uymaya istekli hastalar için konservatif yaklaşım öncelikli olarak önerilmektedir (RCOG kanıt düzeyi B) $(1,2,11)$. Başarı oranı vaka seçimine bağlı olmakla birlikte \%57-100 arasında rapor edilmiştir (12).

Konservatif tedavide yönetim şu şekildedir;

- Hemodinamisi stabil ise ilk testten sonra 2, 4 ve 7 . günlerde $\beta$-hCG ölçümünün tekrarlanması,

- $\quad 2,4$ ve 7 günlerde ölçülen $\beta$-hCG seviyeleri bir önceki değerden $\% 15$ veya daha fazla düşükse, negatif sonuç (20 IU/L'den az) elde edilene kadar haftada bir tekrarlanması,

- $\quad \beta$-hCG seviyeleri \%15 düşmezse, aynı kalır veya önceki değerden daha yüksek ise klinik durum göz önüne alınarak uzmana danışılması gerekmektedir $(2,11)$.

Hastanın genel durumunun bozulması, rüptür belirtilerinin varlığı veya $\beta$-hCG seviyelerinde azalmanın olmaması durumunda bekleme yaklaşımı sonlandırılır (1).

\section{Konservatif Yaklaşımda Ebelik/Hemşirelik Bakımı}

Sağlık çalışanları gebelik kaybının kadın ve partneri için önemli sorunlara neden olabileceğinin farkında olmalı ve danışmanlık verirken hassas davranmalıdır. Ektopik gebelik tanısı alan kadınlara bakım veren ebe ve hemşireler, nasıl iletişim kuracakları ve olumsuz haberleri nasıl verebilecekleri konusunda eğitim almış olmalıdır (13). Konservatif yaklaşımda en önemli nokta hastanın tedaviye uyumu ve bilgilendirilmesidir. Hasta tubal rüptür riski ve yakın gözlem ihtiyacı konusunda kapsamlı danışmanlık almalıdır $(1,2)$. Düşük veya azalan $\beta$-hCG seviyelerinde bile rüptür riski mevcuttur. Bu nedenle rüptür belirti ve bulguları hastaya anlatılmalı, kontrollerin önemi vurgulanmalıdır (1). Mevcut semptomlar kötüleşirse veya yeni semptomlar gelişirse sağlık kuruluşuna başvurması gerektiği belirtilmeli ve iletişim kurabileceği telefon numaraları verilmelidir. Özellikle poliklinik izlemi ile takip edilen hastalarda, ağır aktivite içeren işlemlerden ve koitustan kaçınması konusunda bilgilendirilmelidirler $(2,14)$. Takip süreci sonrasında kadınların anksiyete ve depresyon durumları değerlendirilerek yeni bir gebelik planlaması durumunda üreme sağlı̆̆ danışmanlığı verilmelidir.

\section{Medikal Tedavi}

Cerrahi yaklaşımlar ektopik gebelik için temel tedavi yöntemi iken, erken tanı yöntemlerindeki ilerlemeler sonucunda birçok hasta medikal tedaviye aday haline gelmiştir. Doğru seçilmiş hastalarda medikal tedavinin başarı oranı neredeyse \%90'dır (14). Ameliyatın olası komplikasyonlarının önlenmesi, tüp açıklığının ve fonksiyonunun korunması ayrıca düşük maliyetli olması medikal tedavinin avantajları arasındadır (1). Medikal tedavide en sık kullanılan ajan karaciğerde metabolize olup böbreklerden atılımı sağlanan bir folik asit antagonisti; metotreksattır $(1,3,11)$. Metotreksat, DNA sentezini ve hücre replikasyonunu inhibe ederek kemik iliği, bukkal ve bağırsak mukozası, solunum epiteli, malign hücreler ve trofoblastik doku gibi aktif olarak çoğalan dokuları etkiler (1). Sistemik metotreksat, 1956'dan beri gestasyonel trofoblastik hastalığı tedavi etmek için kullanılmaktadır. Metotreksat yararı kanıtlanmış bir tedavi ajanı olup ilk olarak 1982 yılında Tanaka ve ark. tarafından kullanılmıştır $(15,16)$. Başlangıçta çoklu doz şeklinde uygulanan metotreksatın Stovall ve ark. (1991) tarafından tek doz uygulamasındaki etkinliğinin ortaya konmasının ardından daha az yan etki, daha az komplikasyon oranı ve hasta uyumunun daha iyi olması nedeniyle bu protokol en sık kullanılan tedavi şekli olmuştur $(1,3,16,17)$.

Bir intrauterin gebelik dışlanmadığı ve ektopik gebelik teşhisi kesinleşmediği sürece metotreksat tedavisine başlanmamalıdır. Ek olarak anemi, lökopeni veya trombositopeni ile serum kreatinininde veya kemik iliği işlev bozukluğunda klinik olarak anlamlı yükselmeler bulunan hastalarda metotreksat uygulamasından kaçınılmalıdır. Metotreksat, kan diskrazisi, aktif gastrointestinal veya solunum sistemi hastalığı, karaciğer veya böbrek hastalığı olan kadınlarda kullanılmamalıdır (1-3).

Adaylar:

- Hasta tedaviye uyum sağlayıp, takiplere düzenli gelebilmeli,

- Acil durumlarda merkeze ulaşabilecek konumda olmalı,

- Ektopik kitle boyutu $3.5 \mathrm{~cm}$ 'i geçmemiş olmal1,

- Ultrasonda fetal kalp aktivitesi olmamali,

- Hastanın hemodinamisi stabil olmalı, rüptür belirtisi olmamalıdır,

- $\quad \beta$-hCG seviyesi $<5000 \mathrm{mIU} / \mathrm{ml}$ olmalı,

- Metotreksat tedavisi için kontrendikasyon olmamalıdır $(2,3,11)$.

Ektopik gebelikte metotreksat tek doz, ikili doz ve değişken (multiple) doz şeklinde intramüsküler olarak uygulanır $(1,3)$. Bunların dışında kitle içerisine direkt enjeksiyon şeklinde uygulamalar da mevcuttur (18-20). 


\section{Tek Doz Protokolü}

Tek doz metotreksat tedavisinin etkinliği ilk kez Stovall ve ark (1991) tarafindan ortaya konmuştur. 120 ektopik gebelik tanısı almış kadından oluşan prospektif bir kohort çalışmasında tek doz metotreksat uygulaması sonrası 113 kadının başarı ile tedavi edildiği sadece 7 kadında 2. doz metoreksat uygulamasına ihtiyaç duyulduğu kaydedilmiştir (17). Tedavi etkinliğinin gösterilmesinden sonra daha az yan etki, daha az komplikasyon oranı ve hasta uyumunun daha iyi olması nedeniyle tek doz rejimi en sık kullanılan tedavi yöntemlerinden biri olmuştur $(3,16)$. Serum $\beta$-hCG, tam kan sayımı, karaciğer fonksiyon testleri, serum kreatinin, kan grubu, Rh tayini, PA-akciğer grafisinin (pulmoner hastalık öyküsüne sahip kadınlarda interstisyel pnömoni riski için) ardından tek doz $(50 \mathrm{mg} / \mathrm{m} 2)$ metotreksat uygulaması yapılır. Tedaviden sonraki 4. ve 7. günlerde $\beta$-hCG'de $\% 15$ 'ten daha fazla azalma olması, medikal tedavinin başarısını göstermektedir. Eğer azalma $\% 15^{\prime}$ ten azsa, intramüsküler $50 \mathrm{mg} / \mathrm{m} 2$ ' lık bir doz metotreksat daha yapılır ve $\beta$-hCG seviyesi tekrarlanır. $\beta$-hCG iki dozdan sonra düşmezse, cerrahi tedavinin düşünülmesi gerektiği belirtilmektedir $(2,3,11)$. Tek-doz protokol uygulanan hastaların \%14'ünde iki veya daha fazla doz gerekmektedir. Çoklu-doz protokol uygulanan hastaların ise \%10'unda yalnızca tek bir doz yeterli olmaktadır (14). AAFP tarafından başlangıçta düşük $\beta$ hCG seviyesine sahip hastalarda tez doz protokolünün kanıt düzeyi C olarak belirtilmektedir (1).

\section{İki Doz Protokolü}

İki doz rejimi, ilk olarak 2007 'de, tek doz rejiminin olumlu yan etki profili ile çoklu doz protokolünün etkinliğini birleştirmek amacıyla önerilmiştir. İki doz rejimi, tek doz rejimi ile aynı $\beta$-hCG izleme programına uyar, ancak tedavinin 4. gününde ikinci bir metotreksat dozu uygulanır (3).

Değişken (Çoklu/Multiple) Doz Protokolü

Alternatif rejim olarak çoklu metotreksat ile folik asit uygulanmaktadır (1.3. 5. ve 7. günlerde $1 \mathrm{mg} / \mathrm{kg}$ metotreksat, 2 . 4. 6. ve 8. günlerde folinik asit). Tedavi sırasında günlük $\beta$-hCG seviyeleri ölçülmeli, dört dozdan sonra $\beta$-hCG azalmazsa cerrahi tedavi düşünülmelidir (3).

Medikal tedavi türlerinin karşılaştırıldığı bir meta-analiz çalışmasında, tek doz ile çoklu doz sonuçları arasında anlamlı fark bulunmazken iki doz metotreksat protokolünün, özellikle yüksek $\beta$-hCG ve büyük adneksiyal kitleye sahip hastalarda daha üstün olduğu belirtilmiş, medikal tedavi uygulama tercih edilen hastalarda iki doz uygulaması birinci basamak protokol olarak önerilmiştir (19).

Doğrudan/Lokal Enjeksiyon Rejimleri

Ektopik gebelik konusunda var olan bilgilerimize göre jinekoloji literatüründe, doğrudan/lokal enjeksiyon rejimlerinin çoklu doz ve tek doz metotreksat rejimlerinden daha düşük bir başarı oranı gösterdiği belirtilmektedir. Ayrıca, doğrudan/lokal enjeksiyon rejimleri daha çok sezaryen skar gebeliği ve servikal gebelik gibi nadir görülen lokalizasyonlardaki bazı vakalarda tercih edilmekte olup doğrudan enjeksiyonun avantajı, daha az sistemik toksik etkinin yanı sıra, ilgili dokuya daha yüksek aktif madde konsantrasyonunun verilmesidir (20).

Metotreksatta ciddi toksik etki potansiyeli mevcut olmasına rağmen, ektopik gebeliği olan hastalarda düşük doz kullanıldığı için genellikle hafif ve sınırlı reaksiyonlara neden olur. Sık görülen yan etkiler; bulantı ve kusma, idrar sıklığında artış ve hafif diyaredir. Karaciğer enzimlerinin yükselmesi daha az bildirilen bir yan etkidir ve metotreksat kullanımının kesilmesinden sonra düzelir $(1,3)$.

Metotreksat tedavisi sonrası seri ultrasonografik değerlendirme gereksizdir. Ultrasonografik bulgular yeni bir tubal rüptür olmadığı sürece tedavi başarısızlığını göstermez ve tahmin edemez. Ultrasonografinin persistan ağrı, artan $\beta$-hCG ve tubal rüptür şüphesi durumlarında yararlı olduğu belirtilmektedir (3).

ABD Gıda ve İlaç İdaresi (FDA) metotreksatın ürün etiketinde, kadınların tedavi sırasında ve sonrasında en az bir menstruasyon döngüsü için yeni bir gebelikten kaçınmalarını önermektedir. Bununla birlikte, metotreksat tedavisini başladıktan 116 gün sonra karaciğer hücrelerinde metotreksat varlığı rapor eden çalışmalar mevcuttur. Sinırlı kanıtlar, metotreksat maruziyetinden kısa bir süre sonra gebe kalmış olan kadınlarda konjenital anomalilerin veya erken gebelik kaybının sıklığında artma olmadığını göstermektedir. Bazı rehberler kadınların son metotreksat dozundan sonra en az 3 ay gebeliği ertelemelerini önermektedir (3).

\section{Medikal Tedavide Ebelik/Hemşirelik Bakımı}

Medikal tedavi alan kadınlara verilecek bakım ve danışmanlık, tedaviye uyumu ve tedavi başarısını artırmada önemlidir. Tedaviden önce, kadınlar ilacın etkileri konusunda bilgilendirilmelidir. Özellikle konservatif tedavi uygulanan hastalar, fallop tüp rüptürü semptomları (karın, kasık ve omuz ağrısı, bayılma, güçsüzlük, halsizlik, hipotansiyon, titreme, solukluk, taşikardi, siyanoz) hakkında bilgilendirilmeli, bu semptomlar ortaya çıkarsa derhal tıbbi yardım almanın gerekliliği belirtilmelidir. Ektopik gebelik rüptürü riski ortadan kalkana kadar şiddetli aktivite ve cinsel ilişkiden kaçınılmalıdır. Folik asit takviyesi (folik asit içeren gıdaların metotreksatın etkinliğini azaltabildiğinden) ve nonsteroid antienflamatuar ilaçların (metotreksat toksititesine neden olabileceğinden) alınmaması gerektiği belirtilmelidir. Narkotik analjezik ilaçlar rüptür bulgularını maskeleyebileceği için, alkol ve gaz üreten yiyeceklerin ise gastrointerstinal sistemde neden olduğu değişiklikler rüptür bulguları ile karışabileceği için önerilmemektedir. Bu nedenle ilaç kullanımı ve beslenme düzeni ile ilgili bilgi verilmelidir. Metotreksat, dermatite neden olabileceğinden dermatit riskini önlemek için tedavi sırasında hastanın güneşı ş̧ı̆ına maruz kalmaması konusunda uyarıda bulunulmalıdır $(3,11)$. Her ne kadar kanitlar sınırlı olsa da, metotreksat tedavisi gelecekteki fertilite ve over rezervi üzerinde olumsuz bir etkiye sahip değildir. Yine de kadınlara, uygulanan medikal tedavinin doğurganlık üzerine olabilecek etkisi konusunda mutlaka bilgilendirme yapilmalıdır $(2,3)$.

\section{Cerrahi Tedavi}

Ektopik gebeliğin medikal ya da cerrahi tedavisine ilişkin karar, klinik, laboratuvar ve radyolojik veriler ışığında her bir tedavinin yararları ve risklerinin tartışılmasına ve hastanın her aşamada bilgilendirilmesine dayanan bir yaklaşım ile yönetilmelidir (3). Cerrahi seçenek olarak salpenjektomi (tuba uterinanın tamamının çıkarılması) veya salpingostomi 
(tuba uterinadaki gebelik içeriğini boşaltma amacıyla tüp üzerinde ameliyatla yapay delik oluşturma) laparoskopi veya laparotomi ile yapılır (1). Bu seçenekler arasından mümkün olduğunca laparoskopi tercih edilmelidir (RCOG kanıt düzeyi A). İyi donanımlı bir merkezde, uzman endoskopik cerrah tarafından yapılan laparoskopik salpenjektomi ya da salpingostominin, laparotomiden daha iyi olduğu belirtilmektedir $(2,3,11)$. Genel olarak, salpenjektomi, ciddi fallop tüpü hasarı tespit edildiğinde ve kanamanın fazla olduğu durumlarda tercih edilen yaklaşımdır. Salpenjektomi; sağlıklı kontralateral fallop tüpü olan ve doğurganlığını devam ettirmek isteyen hastalarda göz önünde bulundurulabilir (RCOG kanıt düzeyi B). Bununla birlikte, doğurganlık isteyen ancak fallop tüpünün çıkarılması gelecekte yardımcı üreme teknolojisi desteği gerektirecek hastalarda salpingostomi düşünülmelidir. Salpingostomi yapıldığında, ektopik trofoblastik dokuların durumunu belirlemek için hastayı seri $\beta$-hCG ölçümü ile izlemek önemlidir. Eksik rezeksiyon ile ilgili endişe varsa, tek bir profilaktik metotreksat dozu önerilmektedir $(2,3)$. Tedavi yaklaşımı ne olursa olsun, $\beta$-hCG seviyesini takip etmek son derece önemlidir (1).

Ektopik gebeliğin cerrahi tedavisi için kriterler:

- Rüptüre olmuş ektopik gebelik ile birlikte kollaps veya batın içi kanamanın varlığı,

- Dayanılmaz ağrı,

- $35 \mathrm{~mm}$ veya daha büyük adneksiyal kitle,

- Ultrasonda fetal kalp atışı izlenmesi,

- Serum $\beta$-hCG seviyesinin 5000 IU/L veya daha yüksek olması,

- Hastanın medikal tedaviye uyum sağlayacağından şüphe duyulması,

- Cerrahın laparoskopik uzmanlığı ve ameliyathane ekipmanının yeterli olması $(3,11)$.

Medikal ve cerrahi yönetim maliyet etkinlik ve komplikasyon açısından karşılaştırıldığında; medikal tedavi ile cerrahi ve anestezi riskleri ekarte edilmekle birlikte, laparoskopik salpenjektomi daha yüksek başarı oranına sahiptir $(2,3)$. Medikal tedavi, tanı koymak için laparoskopi gerekmediğinde ve $\beta$-hCG değerlerinin $1.500 \mathrm{mIU} / \mathrm{mL}$ 'den düşük olması durumunda maliyet etkindir ancak yine de daha uzun bir takip süreci gerektirmektedir (3). Ektopik gebeliğin cerrahi tedavisi, sürecin uzaması, $\beta$-hCG değerlerinin artması, embriyonik kardiyak aktivite tespit edilmesi gibi göreceli olarak yüksek bir medikal tedavide başarısızlık olasılığında ise daha düşük maliyetlidir (3). Bu sonuçlar bağlamında uygulanacak tedavi seçiminde belirleyici olan, hastanın klinik durumu, doğurganlık planı ve bilgilendirilmiş onam doğrultusunda kendi verdiği karardır.

Cerrahi Tedavide Ebelik/Hemşirelik Bakımı

Seçilen cerrahi türü, neden tercih edildiği ve olası riskler açısından kadınların bilgilendirilmesi ile verilecek olan bakım ve danışmanlık komplikasyonları önleyerek tedavinin başarısını artırmaktır. Laparoskopik olarak gerçekleştirilen salpenjektomi ya da salpingostomi sonrasında hastanede kalma süresi 24-48 saattir. Rutin verilecek preoperatif ve postoperatif bakımın yanı sıra aşağıdaki konular hakkında bilgilendirme yapılmalıdır:

-Salpingostomi yapılan kadınlara operasyondan sonra 7. günde $\beta$-hCG takibi yapılacağı ve sonuç pozitifse daha fazla değerlendirme gerekeceği, negatif sonuç elde edilene kadar haftada bir takibin devam edeceği,

-Rh negatif kadınlara anti-D IgG profilaksisi yapılması gerektiği,

-Uzun vadede doğurganlık tercihleri, tekrarlayan ektopik gebelik riski ve operasyon sonrası doğurganlık yetenekleri hakkında bilgi verilmelidir $(2,3)$.

\section{Nadir Görülen Ektopik Gebelikler}

Ekstra tubal ektopik gebelikler tüm ektopik gebeliklerin \%10'dan daha azını oluşturur ve daha yüksek morbidite mevcuttur. Yönetiminde öncelikli olarak cerrahi tedavi uygulansa da rehberler incelendiğinde hastanın klinik durumu da göz önünde bulundurularak metotreksat tedavisi ile $\beta$-hCG ölçümleri etkili bir şekilde kullanılmaktadır $(2,3,11)$.

Heterotopik Gebelik

İntrauterin ve ektopik gebeliklerin bir arada bulunması heterotopik gebelik olarak tanılanmaktadır. İlgili literatüre göre; heterotopik gebelikleri teşhis etmek son derece zordur ve vakaların \%50'si sadece tubal rüptür sonrası tanımlanır, eğer intrauterin gebeliğin devamı isteniyorsa, ektopik gebelik cerrahi olarak tedavi edilmelidir (4). Metotreksat, intrauterin gebeliğin devamı uygun olmadığında veya kadın gebeliğe devam etmek istemezse kullanılabilir $(2,3,11)$.

Interstisyel (Kornual) Gebelik

İnterstisyel (kornual) gebelikler ektopik gebelikler içinde en nadir olanıdır ve tüm ektopik gebeliklerin \%2-2.5'ini oluşturur. Gebelik ürünü uterus duvarı içinde kalan, $1 \mathrm{~cm}$ uzunluk ve $1 \mathrm{~mm}$ çaptaki tubaların interstisyel kısmına yerleşir. Yüksek morbidite ve \%2.2 mortalite oranına sahiptir. Klinik semptomlara ve ultrason taramasına dayanarak, eğer kornual gebelik şüphesi varsa, tek serum $\beta$-hCG ölçümü planlama için yararlı olabilmektedir. Yönetim seçenekleri ile ilgili genel karar (cerrahi, medikal veya bekleme) klinik prezentasyona, kornual gebeliğin boyutuna ve serum $\beta$-hCG seviyesine bağlıdır $(2,11)$.

\section{Servikal Gebelik}

Gebeliğin endoservikal kanalda yerleştiği nadir görülen bir ektopik gebelik türüdür. Ultrasonda genellikle boş bir uterus, genişlemiş bir serviks ve internal os’ta gebelik kesesi görülür. Günümüzde erken tanı ile gebeliğin sonlandırılması sağlanarak reprodüktif dönemdeki bu hastalarda histerektomi ihtiyacı azaltılmıştır (21). Sistemik metotreksat ve ultrason eşliğinde fetal kardiyak aktivitenin potasyum enjeksiyonu ile durdurulması gebeliğin sonlandırılmasında uygulanan iki tedavi seçeneğidir. Cerrahi tedavi yöntemleri yüksek başarısızlık oranıyla ilişkilidir ve hayatı tehdit edici kanama varlığında uygulanmaktadır (2).

Ovarian Gebelik

Ektopik gebeliğin nadir bir formu olmasına karşın tuba dışına yerleşen ektopik gebelikler içinde en sık görülenidir. $\beta$ hCG ölçümü ve transvajinal ultrason ile tanı koymak oldukça güçtür. S1klıkla rüptüre tubal ektopik gebelik ya da 
hemorajik korpus luteum kisti gibi yanlış ön tanılar ile hasta ameliyata alındığında tanı kesinleşir $(2,11)$. Yönetiminde laparoskopik over eksizyonu tercih edilir. Sistemik metotreksat, cerrahi risk yüksek olduğunda veya postoperatif persistan rezidüel trofoblast ya da sürekli yükselmiş $\beta$-hCG seviyeleri varlığında kullanılabilir $(2,22,23)$.

\section{Abdominal Gebelik}

Tüm ektopik gebeliklerin yaklaşı \% 1 kadarını oluşturur ve oldukça nadir görülür. Gestasyonel kese genellikle pelvise veya karaciğer ve mezenter gibi yüksek vasküler bölgelere implante olur. Maternal morbidite ve mortalitenin önemli nedenlerindendir (24). Ekstrauterin gebeliklerin diğer türlerinde olduğu gibi USG, abdominal gebeliği teşhis etmek için de kullanılan hızlı bir tanı yöntemidir. Manyetik rezonans görüntüleme (MRG) de abdominal ektopik gebeliği tanılamada ve cerrahi yaklaşımı planlamada yardımcı olabilir. Laparoskopik olarak kesenin alınması erken tanılanan vakalarda tedavi için bir seçenektir. Diğer bir alternatif tedavi yöntemi, ultrason rehberliğinde sistemik metotreksat ile fetosittir. İlerlemiş bir abdominal gebelik ise laparotomi ile tedavi edilmelidir (2). Gebelik haftası ilerledikçe; kanama, fetüsün implante olduğu organın nekrozu veya kaybı, enfeksiyon gibi komplikasyonlar ile maternal mortalite daha sık görülmektedir. Erken tanı maternal sağlık açısından önemlidir (24).

\section{Sezaryen Skar Gebeliği}

Ektopik gebeliğin nadir bir formu olup, son yıllarda sıklığı sezaryen oranlarındaki artışa bağlı olarak artmıştır (25). Tanıda primer olarak TvUSG kullanılır. Boş uterin kavite, boş servikal kanal, gestasyonel kesenin anterior istmik myometriumda izlenmesi sonografik tanı kriterleridir. Tedavi seçenekleri arasında, medikal tedavide metotreksat, keseye potasyum klorid uygulaması, uterin arter embolizasyonu ve cerrahi olarak dilatasyon ve küretaj (D\&C) yer almaktadır. Kanamanın kontrol altına alınamadığı durumlarda ise histerektomi yapılması önerilmektedir $(2,25,26)$.

Nadir görülen gebeliklerde tedavi gebeliğin yerleştiği anatomik bölgeye ve rüptür riskine göre değişmektedir. $\mathrm{Bu}$ nedenle bakım, uygulanacak tedavi doğrultusunda planlanmalıdır.

\section{Sonuç}

Son yıllarda görülme sıklığında artış saptanan ektopik gebelik konusunda var olan bilgilerimize ek olarak jinekoloji literatüründe başvuru kaynağı olan rehberler eşliğinde güncel yaklaşımı gözden geçirdiğimiz bu derleme makalede ACOG, RCOG, NICE ve AAFP önerileri incelenmiş̧ir.

ACOG’a göre; RİA kullanan kadınlarda herhangi bir kontraseptif yöntem kullanmayan kadınlara kıyasla ektopik gebelik riski daha düşük, sezaryen uygulaması ise ektopik gebelik riskinde artışla ilişkilidir. RCOG ise kadınların çoğunda tanımlanabilir bir risk faktörü olmadığını belirtmektedir. AAFP, ACOG ve NICE; ektopik gebeliğin medikal tedavisinde günümüzde de kullanılmakta olan metotreksatı önermeye devam etmektedir. RCOG ve ACOG; tedavi seçeneklerini maliyet etkinlik ve komplikasyon açısından değerlendirerek medikal tedavide cerrahi ve anestezi risklerinin olmadığını, cerrahi tedavinin gerektiği durumlarda laparoskopik salpenjektominin başarısının daha yüksek olduğunu vurgulamaktadır. ACOG; metotreksat tedavisi sonrası seri USG değerlendirmenin gereksiz olduğunu ve kadınların son metotreksat dozundan sonra en az üç ay yeni bir gebeliği ertelemelerini önermektedir.

Bir kadının şüpheli ektopik gebeliği olması durumunda, bunun sağlığı ve doğurganlığı üzerindeki etkisi konusunda kendisine ve partnerine/eşine bilgi verilmesi, rüptüre bir ektopik gebeliğin belirti ve semptomları konusunda uyarılması çok önemlidir. Hastalara bilgi verecek ebe ve hemşireler, rüptürü önleyebilir, ektopik gebeliğin erken teşhisine yardımcı olabilir, böylece sadece ameliyat ihtiyacını en aza indirmekle kalmaz, aynı zamanda potansiyel olarak bir kadının hayatını kurtarabilir. Bu bağlamda ülkemizde ilk trimester gebeliğe bağlı anne ölümlerinin en sık nedeni olan ektopik gebeliğin tanısı, tedavisi ve bakımında hemşirelerin ve ebelerin güncel literatürü takip etmeleri kadın sağlığının korunması ve yükseltilmesi açısından oldukça değerlidir.

\section{Bilgilendirme}

$\mathrm{Bu}$ makalede araştırma konusunun belirlenmesinde her üç yazar eşit görev almıştır. Makalenin literatür taranmasına SBK, yazılmasına SBK ve AH, düzenlenmesine BKS ve AH katkı sağlamıştır. Araştırmacılar arasında herhangi bir çıkar çatışması bulunmamaktadır. Araştırmada herhangi bir fon desteği alınmamışıır. 


\section{Kaynaklar}

1. Hendriks, E., Rosenberg, R., \& Prine, L. Ectopic pregnancy: diagnosis and management. American family physician 2020;101(10): 599-606.

2. Elson CJ, Salim R, Potdar N, Chetty M, Ross JA, Kirk EJ. On behalf of the Royal College of Obstetricians and Gynecologists. Diagnosis and management of ectopic pregnancy. British Journal of Obstetrics and Gynaecology 2016;123:15-55.

3. American College of Obstetricians and Gynaecologists. ACOG Replaces Practice Bulletin Number 191: Tubal Ectopic Pregnancy. Obstetrics \& Gynaecology 2018;131(3): E91-E103.

4. Sabharwal M, Sabharwal S, Chhabra N. Practical Guide in Reproductive Surgery. 1st edition. Gita Mukherjee G, Pal B, Khastgir G. Jaypee Brothers Medical Publishers; 2018: 116-124.

5. Yıldız A, Doğan O. Management and fertility rates of ectopic pregnancies: 5 years single center research. Journal of Clinical Obstetrics \& Gynaecology 2016;26(2):93-97.

6. Ferraretti AP, Goossens V, Kupka M, Bhattacharya S, de Mouzon J, Castilla JA, et al. Assisted reproductive technology in Europe, 2009: results generated from European registers by ESHRE. Human Reproduction 2013;28(9):2318-2331.

7. Akan S, Ediz C, Kızılkan YE, Tavukçu HH, Hayit H, Yılmaz Ö. Evulation of male military staff's level of knowledge about sexually transmitted diseases. The New Journal of Urology 2019;14(3):152-159.

8. Akdemir S, Davarcioğlu Özaktaş F, Aksoy N. Women's status in labor market in Turkey and other selected countries. Karadeniz Uluslararas1 Bilimsel Dergisi 2019;43:184-202.

9. Hacettepe Üniversitesi Nüfus Etütleri Enstitüsü. 2018 Turkey Demographic and Health Survey. Hacettepe Üniversitesi Nüfus Etütleri Enstitüsü, T.C. Cumhurbaşkanlığı Strateji ve Bütçe Başkanlığı ve TÜBİTAK, 2019, Ankara.

10. Backman T, Rauramo I, Huhtala S, Kuskenvuo M. Pregnancy during the use of levonorgestrel intrauterine system. American Journal Obstetric Gynecology 2004;190:50-4.

11. Webster K, Eadon H, Fishburn S, Kumar G. Ectopic pregnancy and miscarriage: diagnosis and initial management: Summary of updated NICE guidance. British Medical Journal 2019; 367.

12. Craig LB, Khan S. Expectant management of ectopic pregnancy. Clinical Obstetrics Gynaecology 2012;55:46170.

13. NICE Pathways. Managing tubal ectopic pregnancy URL: http://pathways.nice.org.uk/pathways/ectopicpregnancy-and-miscarriage 20 Kasım 2020.

14. Barnhart KT, Gosman G, Ashby R, Sammel M. The medical management of ectopic pregnancy: A meta-analysis comparing "single dose" and "multi dose" regimens. Obstetrics \& Gynaecology 2003;101(4):778-784.

15. Tanaka T, Hayashi H, Kutsuzawa T, Fujimoto S, Ichinoe K. Treatment of interstitial ectopic pregnancy with methotrexate: report of a successful case. Fertility and Sterility 1982;37(6):851-2.

16. Alper AGÖ, Büyükbayrak EE, Bayramoğlu MB, Karşıdağ AYK, Kars B, Pirimoğlu ZM, et al. Treatment approaches in ectopic pregnancy: A four year retrospective analysis of a tertiary referral center. Journal of Clinical Obstetrics \& Gynaecology 2010;20(6):362-366.

17. Stovall TG, Ling FW, Gray LA. Single dose methotrexate for treatment of ectopic pregnancy. Obstetric Gynaecology 1991;77(5):754-7.

18. Odejinmi F, Huff KO, Oliver R. Individualisation of intervention for tubal ectopic pregnancy: historical perspectives and the modern evidence based management of ectopic pregnancy. European Journal of Obstetrics \& Gynecology and Reproductive Biology 2017;69-75.

19. Alur-Gupta S, Cooney LG, Senapati S, Sammel MD, Barnhart KT. Two doses versus single dose of methotrexate for treatment of ectopic pregnancy: A meta-analysis. American Journal of Obstetrics and Gynaecology 2019;95108.

20. Tenore JL. Ectopic pregnancy. American Family Physician. 2000;61(4):1080-1088.

21. Uğurel $\mathrm{V}$, Aslan MM. The alternating successive use of two treatment modalities in two cervical pregnancy cases. Firat Tip Dergisi 2015;20(3):175-178.

22. Balcı O, Ercan F, Avunduk MC. Ruptured ovarian pregnancy and its laparoscopic management: Case report. Şişli Etfal Tıp Bülteni 2016;50(4):334-337.

23. Taran FA, Kagan KO, Hübner M, Hoopmann M, Wallwiener D, Brucker S. The diagnosis and treatment of ectopic pregnancy. Deutsches Ärzteblatt International 2015;112(41):693.

24. Şilfeler DB, Güngören A, Dolapçıŏlu K, Karateke A, Güney Ç, Akın MM, et al. Primary abdominal pregnancy: A case report. The Journal of Kartal Training and Research Hospital 2011;22(1):35-37.

25. Biberoğlu EH, Kırbaş A, Daglar HK, Çelen Ş, Çaglar T, Erkaya S, et al. Sezaryen Skar Ektopik Gebelik: Olgu Serisi. Jinekoloji Obstetrik ve Neonatoloji Tip Dergisi 2016;13:4-5.

26. Kurt S, Uyar İ, Gürbüz T, Arıcı A, Demirtaş Ö, Taşyurt A. Treatment of cesarian scar pregnancy with vacuum curettage after systemic methotrexate administration: Report of two cases. Journal of Clinical Obstetrics \& Gynaecology 2013;23(2):123-126. 